\title{
IODP expedition 347: Baltic Sea basin paleoenvironment and biosphere
}

\author{
T. Andrén ${ }^{1}$, B. Barker Jørgensen ${ }^{2}$, C. Cotterill ${ }^{3}$, S. Green ${ }^{3}$, and the IODP expedition 347 scientific party $^{*}$ \\ ${ }^{1}$ School of Natural Sciences, Technology and Environmental Studies Södertörn University, Sweden \\ ${ }^{2}$ Center for Geomicrobiology Department of Bioscience, Aarhus University, Denmark \\ ${ }^{3}$ British Geological Survey, Edinburgh, UK \\ *A full list of authors and their affiliations appears at the end of the paper.
}

Correspondence to: T. Andrén (thomas.andren@sh.se)

Received: 27 September 2015 - Accepted: 23 November 2015 - Published: 17 December 2015

\begin{abstract}
The Integrated Ocean Drilling Program (IODP) expedition 347 cored sediments from different settings of the Baltic Sea covering the last glacial-interglacial cycle. The main aim was to study the geological development of the Baltic Sea in relation to the extreme climate variability of the region with changing ice cover and major shifts in temperature, salinity, and biological communities. Using the Greatship Manisha as a European Consortium for Ocean Research Drilling (ECORD) mission-specific platform, we recovered $1.6 \mathrm{~km}$ of core from nine sites of which four were additionally cored for microbiology. The sites covered the gateway to the North Sea and Atlantic Ocean, several sub-basins in the southern Baltic Sea, a deep basin in the central Baltic Sea, and a river estuary in the north.

The waxing and waning of the Scandinavian ice sheet has profoundly affected the Baltic Sea sediments. During the Weichselian, progressing glaciers reshaped the submarine landscape and displaced sedimentary deposits from earlier Quaternary time. As the glaciers retreated they left a complex pattern of till, sand, and lacustrine clay, which in the basins has since been covered by a thick deposit of Holocene, organic-rich clay. Due to the stratified water column of the brackish Baltic Sea and the recurrent and widespread anoxia, the deeper basins harbor laminated sediments that provide a unique opportunity for high-resolution chronological studies.

The Baltic Sea is a eutrophic intra-continental sea that is strongly impacted by terrestrial runoff and nutrient fluxes. The Holocene deposits are recorded today to be up to $50 \mathrm{~m}$ deep and geochemically affected by diagenetic alterations driven by organic matter degradation. Many of the cored sequences were highly supersaturated with respect to methane, which caused strong degassing upon core recovery. The depth distributions of conservative sea water ions still reflected the transition at the end of the last glaciation from fresh-water clays to Holocene brackish mud. High-resolution sampling and analyses of interstitial water chemistry revealed the intensive mineralization and zonation of the predominant biogeochemical processes. Quantification of microbial cells in the sediments yielded some of the highest cell densities yet recorded by scientific drilling.
\end{abstract}

\section{Introduction}

The Baltic Sea basin (BSB) is one of the world's largest intra-continental basins, occupying $373000 \mathrm{~km}^{2}$ and with a drainage area 4 times this size (Fig. 1). Its mean depth is $\sim 54 \mathrm{~m}$, although a few relatively deep basins exist (e.g., the eastern Gotland Basin, $248 \mathrm{~m}$, and the Landsort Deep, $459 \mathrm{~m})$. The BSB has served as depositional sink throughout at least the last during the last glacial cycle and its sedi- ments comprise a unique high-resolution archive of the paleoenvironmental history of the large drainage area, the basin itself, and the neighboring gateways to the North Sea. The location of the BSB in the heartland of the recurring Scandinavian ice sheet (SIS) has resulted in a complex developmental history, characteristic of many glaciated regions of the Northern Hemisphere: repeated glaciations of different magnitudes, sensitive responses to sea-level and gateway thresh- 


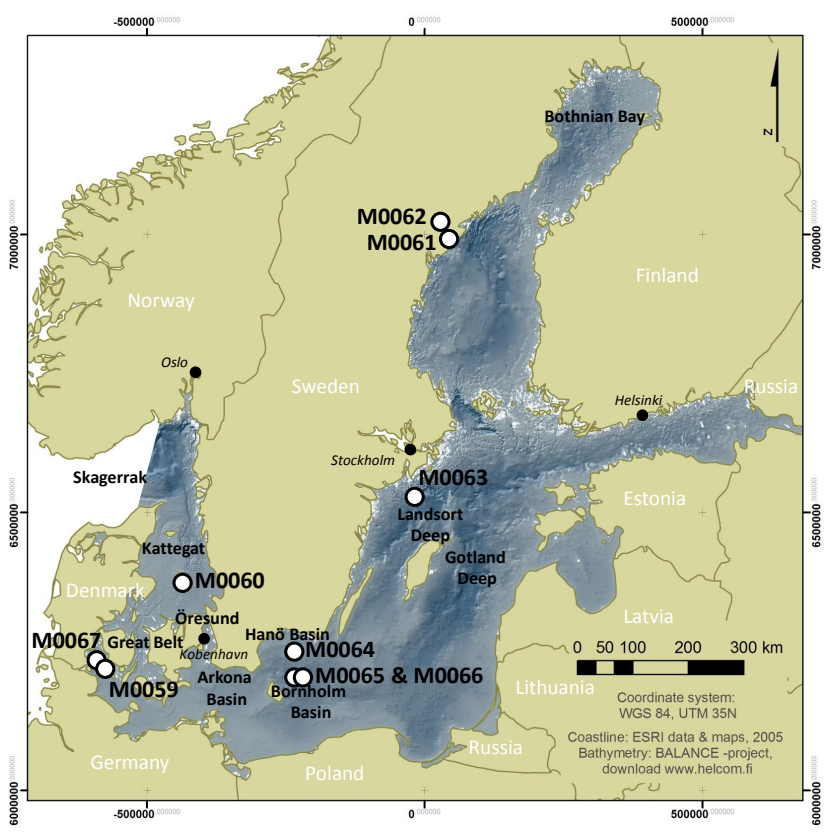

Figure 1. Bathymetric map of the Baltic Sea with the nine coring sites, M0059 to M0067. Source: IODP Leg 347 expedition Report.

old changes, large shifts in sedimentation patterns, and high sedimentation rates.

The geographical position of the BSB makes it a unique link between the Eurasian and the northwest European terrestrial records and as such also serves as a link to the North Atlantic marine records and the Greenland ice cores.

The high sedimentation rates $(100-500 \mathrm{~cm} / 1000$ years) of the BSB provide an excellent opportunity to reconstruct in some parts climate variability of global importance controlled by, for example, changes in meridional overturning circulation (MOC), the North Atlantic Oscillation (NAO), and the Arctic oscillation (AO). These paleoenvironmental reconstructions offers a unique resolution from a marinebrackish setting as some of the sediments can even be resolved on inter-annual timescales. This makes the BSB highly suitable for sediment coring from the last glacial cycle and a unique location to achieve scientific objectives of high-resolution paleoceanography and paleoclimate studies, as comparable sequences cannot be retrieved anywhere in the surrounding onshore regions.

\section{Glacial-interglacial history of the Baltic Sea basin}

The BSB has undergone many glaciations during the Quaternary. During the last interglacial (the Eemian, marine isotope stage (MIS) 5e), the BSB was a larger and more saline sea than the present Baltic Sea (Funder et al., 2002). Only fragments of the Baltic glacial history are known. However, we do know that a Baltic glacial event occurred during MIS 4 as recorded in sediments from northwest Finland at $\sim 64^{\circ} \mathrm{N}$
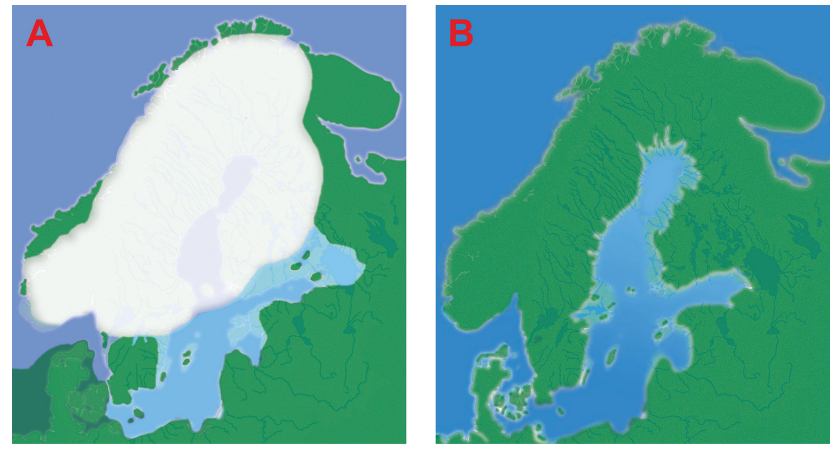

Figure 2. (a) Estimated extension of the Scandinavian ice sheet at $11.7 \mathrm{ky} \mathrm{BP}$ just prior to the final drainage of the Baltic Ice Lake. Dark blue: Atlantic Ocean, light blue: Baltic Ice Lake. (b) Extension of the Littorina Sea during the time of maximum salinity in the Baltic basin at ca. 6 ky BP. Source: Andrén et al. (2011).

(Salonen et al., 2007). The first Baltic ice lobe that advanced into Denmark is dated to $\sim 55-50 \mathrm{ky}$ BP (thousand years before present; Houmark-Nielsen, 2007). From detailed correlations and dating of southwestern Baltic glacial stratigraphies (Houmark-Nielsen and Kjær, 2003), it is proposed that the southwestern Baltic experienced two major ice advances during MIS 3, at $\sim 50$ and $30 \mathrm{ky} \mathrm{BP.} \mathrm{However,} \mathrm{the} \mathrm{latter} \mathrm{is}$ highly debated (e.g., Kjellström et al., 2010). This enigmatic period between $\sim 50$ and $25 \mathrm{ky} \mathrm{BP}$, with its partly incompatible records, was followed by a complex glaciation in the southern BSB (Houmark-Nielsen and Kjær, 2003) leading up to the Last Glacial Maximum.

Deglaciation of the southern BSB between 22 and 16 ky BP was complex, with major deglacial phases interrupted by some intriguing SIS still stands and re-advances (Houmark-Nielsen and Kjær, 2003; Larsen et al., 2009), possibly as surges.

Earlier studies have suggested that the Younger Dryas cold event (12.9 to $11.6 \mathrm{ky} \mathrm{BP}$ ) was caused by freshwater runoff from the Laurentide (American) ice sheet slowing the Atlantic MOC (Marshall and Clark, 1999). However, state-ofthe-art climate models require a continuous freshwater forcing to produce millennia-long cold events (Liu et al., 2009) and there are indications of substantial freshwater forcing from the BSB predating the final drainage from the Baltic Ice Lake (e.g., Björck, 1995; Bennicke and Jensen, 2013).

During the final drainage of the Baltic Ice Lake at $\sim 11.7 \mathrm{ky} \mathrm{BP}$ (Fig. 2a), almost $8000 \mathrm{~km}^{3}$ of freshwater was released rapidly into the North Atlantic (Jakobsson et al., 2007).

The next Baltic Sea stage, the Yoldia Sea, coincided with the onset of the Holocene epoch (Walker et al., 2009) and the associated rapid warming. In fact, the thicknesses of glacial varves in the northwestern Baltic proper and $\delta^{18} \mathrm{O}$ values in ice cores from the Greenland Ice Core Project (GRIP) display a noticeably similar pattern over a 150 -year-long tran- 
sition period from Younger Dryas to pre-Boreal (Andrén et al., 1999, 2002). These records show a distinct increase in sedimentation rate as the ice sheet began to melt and rapidly retreat. The following few hundred years were characterized by rapid deglaciation of the SIS. Relative sea-level lowering of the Yoldia Sea played an important role and were the result of a combination of rapid regression in the recently deglaciated regions and normal regression rates in southern Sweden (1.5-2 m/100 years).

As the outlets to the west became shallower, subsequent damming forced the water level inside the Baltic Basin to rise and the next stage began, the Ancylus Lake. The sediments of this large freshwater lake generally contain little organic material, which may be explained as a result of the large meltwater inflow to the Baltic from the final deglaciation of the SIS and also a result of erosion of the young soils from the recently deglaciated drainage area. This created a lake environment with low nutrient input and hence low productivity. The freshwater environment did not enable the formation of a halocline but led to a well-mixed, oxygenated waterbody. The relatively common sulfide-banded sediments of this stage can probably be explained by later $\mathrm{H}_{2} \mathrm{~S}$ diffusion from overlying, organic-rich Holocene sediments (Sohlenius et al., 2001).

The global melting of the large ice sheets over a couple of millennia caused a $30 \mathrm{~m}$ rise in absolute sea level (Lambeck and Chappell, 2001). A consequence of this was the flooding of the Öresund Strait, believed to be the main gateway for the onset of the marine Littorina Sea stage. The outlets/inlets through Öresund and Great Belt widened and became deeper, resulting in greater water flow and gradually increasing salinity.

The onset of the Littorina Sea stage can often be recognized as a marked lithologic change in Baltic Sea sediment cores. The onset is represented by a distinct increase in organic content and an increasing abundance of brackishmarine diatoms (e.g., Sohlenius et al., 2001).

Periods of deep-water hypoxia in the open Baltic Basin are evident in the sediment record as extended sequences of laminated sediment. The Littorina Sea (Fig. 2b) experienced a sustained period of elevated salinity and resulting hypoxia between 8 and 4 ky BP (Zillén et al., 2008). After $\sim 4$ ky BP, the salinity decreased gradually and oxygen concentrations increased in the bottom waters.

The human population growth and large-scale changes in land use that occurred in the Baltic Sea watershed during the Medieval period between AD 750 and 1300 has been suggested as a triggering mechanism behind the expansion of hypoxia that again occurred at this time (Zillén et al., 2008). Alternative hypotheses suggest that the development of hypoxia in the open Baltic Sea over the past 1000 years has mainly been driven by the climate system (e.g., Kabel et al., 2012).

\section{Scientific objectives}

The objectives of expedition 347 are categorized below.

Geology and climate development objectives include the following:

- to increase our understanding of the climate system and the sea-level dynamics of the last interglacial, including the climatic oscillations at the transition between MIS 6 and MIS 5e, and in the initial, climatically oscillating part of the last glacial (MIS 5d-5a);

- to analyze environmental conditions during the warmest interval of MIS 5e to elucidate possible future scenarios during warmer climate and higher sea-level stands;

- to evaluate how strongly the SIS responded, in time and space, to North Atlantic climate forcing during the last glacial, and to what extent the dynamic alterations of the SIS had an impact on the North Atlantic climate system;

- to understand the feedbacks between the waterbody of the BSB, the SIS, and the North Atlantic circulation;

- to determine to what degree the glacier oscillations of the SIS margin were synchronous on both sides of the main ice divide, centered along the Scandinavian mountain chain, and whether the ice advances into the southern BSB can be recognized as large-scale surges;

- to describe how the highly oscillating climate pattern of MIS 3 is recorded at the northeast margin of the North Atlantic in long and continuous sediment sequences in the BSB;

- to analyze if there are solar forcing signals in the melting record of the shrinking ice sheet or in the precipitation-related fluvial system;

- to reconstruct river discharge (and thereby also precipitation) with annual resolution, several millennia back in time;

- to determine how the in- and outflows to the Baltic Sea have varied over time, and how this is related to changes in large-scale atmospheric circulation and sea level (threshold depths);

- to analyze how the general precipitation pattern, which is linked to the dominating AO-NAO system over the northern circum-Atlantic and circum-Arctic region, change during the Holocene.

Microbiology and geochemistry objectives include the following:

- to understand how microbial cell numbers are controlled in relation to depth, age, lithology, and other environmental parameters in relatively young and organicrich marine sediments; 
- to determine the diversity and activity of subsurface microbial communities through metagenomic, metatranscriptomic, and single-cell genomic analyses;

- to determine whether the predominant microorganisms are selected by environmental conditions prevailing in the subsurface today;

- to determine whether the sub-seafloor microbial communities reflect past environmental conditions, e.g., seawater or freshwater, cold or temperate climate, oxic or anoxic bottom water;

- to analyze whether viruses and unicellular eukaryotes play a role in the subsurface sediments;

- to model and interpret past climate and paleoenvironment of the Baltic Sea basin from geochemical proxies;

- to analyze how the major glacial-interglacial shifts in the Baltic Sea affect sediment geochemistry today;

- to understand how nutrient loading, organic productivity and hypoxia have varied in the Baltic Sea throughout the Holocene and what are the forcing factors.

\section{Coring operations and strategy}

The drilling platform chosen for expedition 347 was the Greatship Manisha, an IMO (International Maritime Organization) Class II dynamically positioned vessel with geotechnical coring capability (Fig. 3a). The mobilization took place in Falmouth prior to transit to Kiel, Germany, where the ESO (ECORD (European Consortium for Ocean Research Drilling) Science Operator) expedition project managers and offshore science party participants boarded the vessel following a pre-cruise scientific meeting in Copenhagen. Operations were conducted between 12 September and 1 November, with demobilization of the vessel occurring back in Falmouth on 5 and 6 November. In total, 37.1 days of expedition 347 were spent operational on station, 8.5 days in transit between sites, 1.3 days in port, 1.3 days on standby at station because of weather, and 1.8 days on equipment-related downtime.

The vessel was equipped with a large moon pool and Geoquip GMTR 120 heave-compensated derrick, with a 120 metric ton capacity top drive. Pipe handling was carried out using a proprietary semiautomated handling system utilizing a pipe handling crane with grab, a remotely operated iron roughneck, and a proprietary catwalk system. A $4 \mathrm{~m}$ stroke passive heave compensation (semiactive under development) was achieved using nitrogen gas as a compensation buffer with Olmsted valve slingshot protection. The rig was used in association with a 12 metric ton seabed template, fitted with clamps and seabed transponder, to provide the reaction force for in-hole tools. Wireline operation of the core barrel was conducted through the top drive.
Five methods of wireline coring were employed in addition to open-hole drilling using a non-coring assembly. The primary coring tool was a piston corer system (PCS), operated by advancing the core barrel into the formation through hydraulic pushing. However, where formation lithologies were either unconsolidated, noncohesive, friable or very hard, an extended coring system (ECS), non-rotating core barrel system (NRCB), push coring assembly (PCA), or hammer sampler (HS) were employed. The HS was the most rudimentary system used during this expedition, consisting of a built-in hammer, which was raised and lowered onto an anvil over a few meters distance. This tool was used to obtain a spot sample when open-holing through coarser-grained deposits, or when conventional coring methods had been unable to acquire a sample. The non-coring assemble (NCA) used a Tricone Rock Roller drill bit to plug the hole in the main core bit to advance without recovery.

The core collected was $62 \mathrm{~mm}$ in diameter. The maximum core run length was $3.3 \mathrm{~m}$. However, the length of a core run was chosen to maximize core recovery and quality while maintaining hole stability, even at the expense of overall penetration speed. When attempting to capture a lithologic interface, as defined from seismic profiles, the run lengths were often shortened by raising the corer above the bottom of the borehole by a known height prior to pressuring the drill string. In some instances, the hole was advanced by open holing - drilling ahead without recovering sediments. This was done in difficult lithologies that could not be recovered conventionally to enable recovery of other lithologies beneath these intervals or when recovery (composite or from an individual hole) of an interval had already reached $>90 \%$, and the scientific rationale was to try and get deeper within the time constraints. The advance varied from a small offset of $0.5 \mathrm{~m}$ to ensure maximum core overlap between holes in some locations to a more regular spacing of $3 \mathrm{~m}$ through the till lithologies to monitor when or whether the lithology was changing.

At the Ångermanälven River estuary site (M0061), there were initial restrictions on coring the upper $50 \mathrm{~cm}$ of sediment due to potential heavy metal contamination from industry. This was relaxed on assessment on-site. At Hanö Bay, Bornholm basin, and Anholt loch sites (M0064, M0065, and M0060, respectively), downpipe camera or ROV (remotely operated vehicle) surveys were conducted prior to commencing coring, due to the potential for dumped WWII munitions on the seabed. In addition, restrictions were placed on coring the upper $2 \mathrm{~m}$ of sediment at Bornholm Basin (M0065) due to the risk of dumped chemical munitions.

Offshore, the cores from paleo-oceanographic designated holes were carefully curated by ESO staff before ephemeral physical (multi-sensor core logger, MSCL) and geochemical properties were measured and preliminary core catcher samples taken. Initial lithological and micropaleontological descriptions were conducted by visual inspection through the liner and by using core catcher materials. No further sam- 


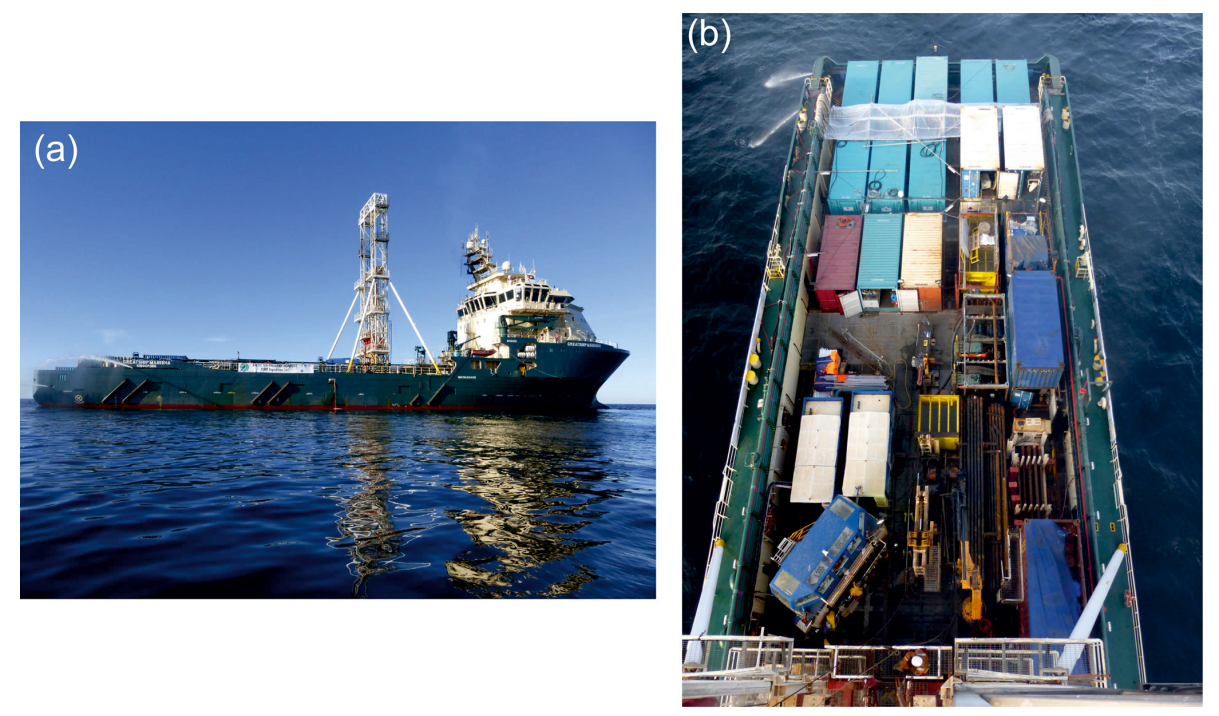

Figure 3. (a) The geotechnical vessel, Greatship Manisha (of Singapore) equipped with a drilling derrick. (b) View from the derrick over the drill deck at mid-ship and the "science garden" to the aft. Image copyright ECORD/IODP.

pling, core splitting, or analysis work was undertaken offshore.

On microbiological designated holes, samples were taken on the drill floor from the cut ends of core sections to capture ephemeral properties, including methane gas and contamination tracer quantities. The cores were then curated and run through a fast-track MSCL prior to extensive sampling in the designated laboratory containers (Fig. 3b) for microbiological research and for interstitial water analyses. In total $>5800$ samples were taken offshore.

All cores, core catchers, headspace gas samples, interstitial water splits, and digital data were transferred to the Integrated Ocean Drilling Program (IODP) core repository in Bremen, Germany (BCR), at the end of the offshore phase. Prior to the start of the Onshore Science Party (OSP), additional thermal conductivity measurements and natural gamma radiation measurements were conducted on whole core sections. The complete science party, as well as ESO and BCR personnel and student helpers, met at the BCR from 22 January to 21 February to split, analyze, and sample the cores according to standard IODP procedures, and for postcruise scientific research.

\section{Preliminary expedition results}

In the following we present selected preliminary results from leg 347 on lithology, biostratigraphy, dating, geochemistry, and microbiology. By these chosen examples we briefly summarize how the expedition met some of the objectives outlined above.

\subsection{Little Belt (sites M0059 and M0067)}

The lithology consists of diamicton interlayered with sand and silt in the lower part of the core (Fig. 4a). These layers give OSL (optically stimulated luminescence) ages between ca. $362 \mathrm{ky} \mathrm{BP}$ at $146 \mathrm{~m}$ b.s.f. (meters below seafloor) and ca. $103 \mathrm{ky} \mathrm{BP}$ at $108 \mathrm{~m}$ b.s.f. This means that the sediments between these two levels have recorded MIS 5. The recovered stratigraphy is, however, fragmented but represents nonetheless a unique archive of a Pleistocene time window never recovered before in the Baltic Sea. On top of this unit, at $\sim 90-83 \mathrm{~m}$ b.s.f., is a $11 \mathrm{~m}$ thick sandy deposit with silt and clay laminas. The OSL date from these sediments is ca. 44 ky BP.

From 82 to $52 \mathrm{~m}$ b.s.f., glacial ice lake sediment is deposited as varved glacial clay displaying thick varves in the lower part and thinner varves deposited distal to the retreating ice margin in the upper part. This unit is erosionally truncated and marked by a $2 \mathrm{~cm}$ thick sandy-silty layer at $52 \mathrm{~m}$ b.s.f. displaying an upwards coarsening, which indicates deposition during a rapid regression. The contact upwards to the overlaying gyttja clay is sharp and possibly also erosional.

At site M0059 we recovered $52 \mathrm{~m}$ of Holocene sediment with a correspondingly high-mean sedimentation rate of 5$7 \mathrm{~mm}$ year $^{-1}$ based on four radiocarbon dates received so far. The diatom flora in this unit of organic-rich clay has recorded a sharp transition from freshwater to fully marine conditions at ca. $48 \mathrm{~m}$ b.s.f., indicating a rapid marine transgression (Fig. 4c). It should be noted, however, that final conclusions cannot be drawn until the sequence has become more thoroughly analyzed.

From site M0067 we only recovered ca. $4.4 \mathrm{~m}$ of Holocene mud on top of medium to coarse sand interlayered with silt 
(a)

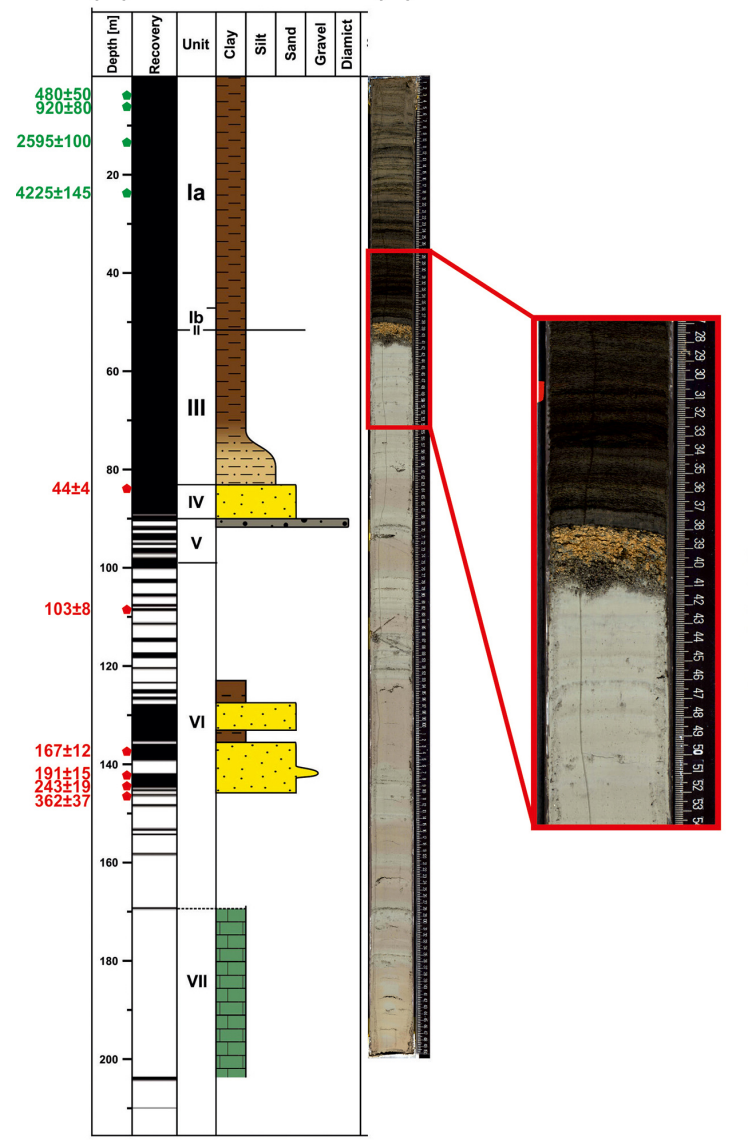

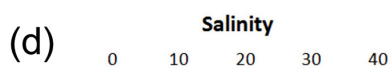

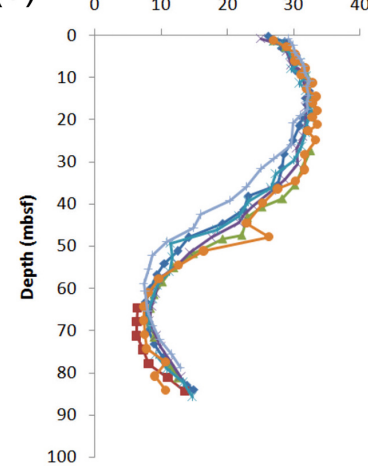

(b)

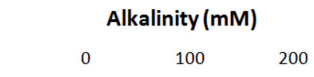

(c)
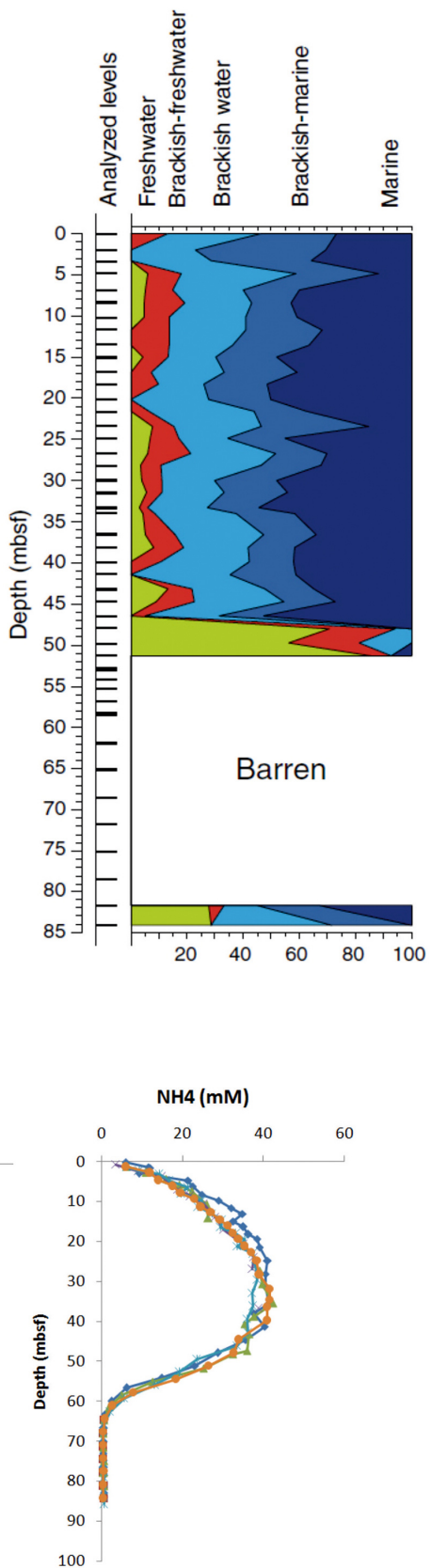

Figure 4. Little Belt, site M0059. (a)Lithostratography with ages: green is ages derived from ${ }^{14} \mathrm{C}$ dating given in cal yr BP and red is ages derived from OSL dating given in ky BP. (b) Section 347-M0059A-16H-2 from $52 \mathrm{~m}$ b.s.f. shows the hiatus sand horizon of unit II at the transition from the varved clay sequence of Unit III into the laminated black organic-rich clay of subunit Ib. Inset: close-up of the coarsegrained, poorly sorted sand hiatus marking a low stand. (c) Relative distributions of diatom taxa according to their preferred habitat salinity. (d) Examples of interstitial water chemistry: diffraction-based salinity, alkalinity, and ammonium. Different symbols show data from different holes.

and clay, interpreted having a glaciofluvial ice-proximal origin. There is obviously a large hiatus at this site.

The depth distributions of conservative seawater ions in the interstitial water showed a distinct drop from seawater salinity in the Holocene sequence to a minimum in salin- ity in the underlying glacial ice lake clay (Fig. 4d). Interestingly, chloride-based salinity calculations did not show a broad maximum at $10-30 \mathrm{~m}$ b.s.f. as did the diffraction-based salinity, which is affected by all ions in the interstitial water. The difference is due to very high DIC (dissolved in- 
organic carbon) and ammonium concentrations that add to the diffraction-based salinity. These data reflect extremely high rates of organic matter mineralization in the $50 \mathrm{~m}$ deep, organic-rich Holocene clay. Thus, alkalinity values were up to $200 \mathrm{mM}$, which is probably a new IODP record, while ammonium reached $40 \mathrm{mM}$.

\subsection{Kattegat (site M0060)}

From site M0060 we cored a $>200 \mathrm{~m}$ deep, almost continuous record that consists of an $84 \mathrm{~m}$ diamict unit, in the lowermost part of the core. On top of this unit alternating sandy and silty sequences are recorded with a unit between 79 and $6 \mathrm{~m}$ b.s.f. that consists of varved glacial clay indicating deposition in a glacial lake or marginal marine environment. It is possible that this varved unit records freshwater outflow from the Baltic basin, and it is therefore anticipated that it will give a yearly resolution.

A gradually decreasing salinity was recorded down to ca. $125 \mathrm{~m}$ b.s.f. at this site below, which the salinity increased distinctly again. Together with the foraminifera and ostracode records this indicates a marine provenance of the sediments below this level. Throughout the hole, cores also displayed abundant snail and bivalve shells that will be useful for both dating and environmental reconstruction.

The sediment had surprisingly low mineralization rates with mainly sulfate reduction and iron reduction as the dominant terminal processes of organic matter oxidation. Methane appeared only at depths between 100 and $170 \mathrm{~m}$ b.s.f. This methane is possibly not produced on site in the low-organic diamict unit but may have been transported over a distance via the over-pressured sandy aquifer.

\section{3 Ångermanälven River estuary (sites M0061 and M0062)}

These two northernmost sites were selected as it was known that annual varves have been deposited over several thousand years and are still being formed at the mouth of the river. The many hundred years of varved sequences collected at these sites will be correlated with and included in the socalled Swedish Time Scale, a continuous varve chronology covering the time span from ca. 13300 clay-varve years BP to the present.

At both sites ca. $20 \mathrm{~m}$ of sediments were recovered, which displayed varves that were $4-10 \mathrm{~cm}$ thick in the lower part and only a few millimeters thick in the upper part. At site M0061 organic-rich mud in the uppermost $8 \mathrm{~m}$ displayed a brackish influence that was evident from both the foraminifer and ostracode fauna and from the diatom flora. It is noteworthy that this is the first report of foraminifers and ostracodes in sediments of Holocene age this far north in the Baltic Sea.

\subsection{Landsort Deep (site M0063)}

In the Landsort Deep, which is the deepest basin in the Baltic Sea, we cored to a depth of $95 \mathrm{~m}$ b.s.f. in a water depth of $437 \mathrm{~m}$. At the deepest part between 95.8 and $93.4 \mathrm{~m}$ b.s.f. the sediment consists of a clast-poor sandy diamicton overlaid by a $53 \mathrm{~m}$ thick unit of varved glacial clay. This uniquely long varve sequence may enable a correlation to the Greenland ice core record (cf. Andrén et al., 1999, 2002). The varves can possibly comprise as much as 2,000 years in one continuous sedimentary record and may have recorded, with annual resolution, the entire Younger Dryas as well as its onset and termination (Fig. 5). In the upper part of this varved unit at $41.5 \mathrm{~m}$ b.s.f. a weak brackish influence is recorded in both the ostracode fauna and in the diatom flora, which is interpreted as representing the short brackish phase of the Yoldia Sea stage.

The overlaying grey homogenous clay converts gradually into a laminated organic-rich mud and the first substantial inflows of marine water are registered at $28 \mathrm{~m}$ b.s.f., as observed from a decrease in freshwater and increase in brackish water diatom species and an increased abundance of foraminifers. This first inflow is also registered as an increasing salinity in the chemistry of the pore-water and probably represents the transition from the lacustrine Ancylus Lake stage to the brackish-marine Littorina Sea stage.

The uppermost $28 \mathrm{~m}$ of the cored sediments consists of a laminated organic-rich mud, sometimes referred to as clay gyttja in Baltic Sea geological literature. This type of sediment indicates that the deepest part of the Landsort Deep has been anoxic/hypoxic during the last ca. 7000 years. So far we have only one ${ }^{14} \mathrm{C}$ date from this unit at $24.6 \mathrm{~m}$ b.s.f. yielding an age of $5850 \pm 120 \mathrm{cal} \mathrm{yr} \mathrm{BP}$.

\subsection{Hanö Bay (site M0064)}

Four holes were drilled at this site of which three recovered an almost $30 \mathrm{~m}$ long unit of clast-rich, stratified, muddy diamicton on top of a unit of sandy clayey silt with thin intervals of diamicton. Varved glacial clay deposited on top of this diamicton consisted of two different sub-units, a lower dark-brownish-grey clay and an upper dark-greyish-brown clay separated by a $2-3 \mathrm{~cm}$ thick organic-rich (LOI, loss on ignition; ca. $8 \%$ ) brown silty clay $(84-87 \mathrm{~cm}$ in section (b), Fig. 6). This unit has been ${ }^{14} \mathrm{C}$ dated in two cores and the mean age of the unit is $45700 \pm 1500$ cal yr BP, which means that this lower varved clay sequence was deposited during a deglaciation much older than the latest one.

\subsection{Bornholm Basin (sites M0065 and M0066)}

The lithologies from these two sites are quite similar. The lowermost $40 \mathrm{~m}$ of the stratigraphy consists of the same two different types of varved glacial clays as at site M0064 although more expanded. Also at site M0065 the two clay units are separated by a homogenous dark-grey layer, here with a 


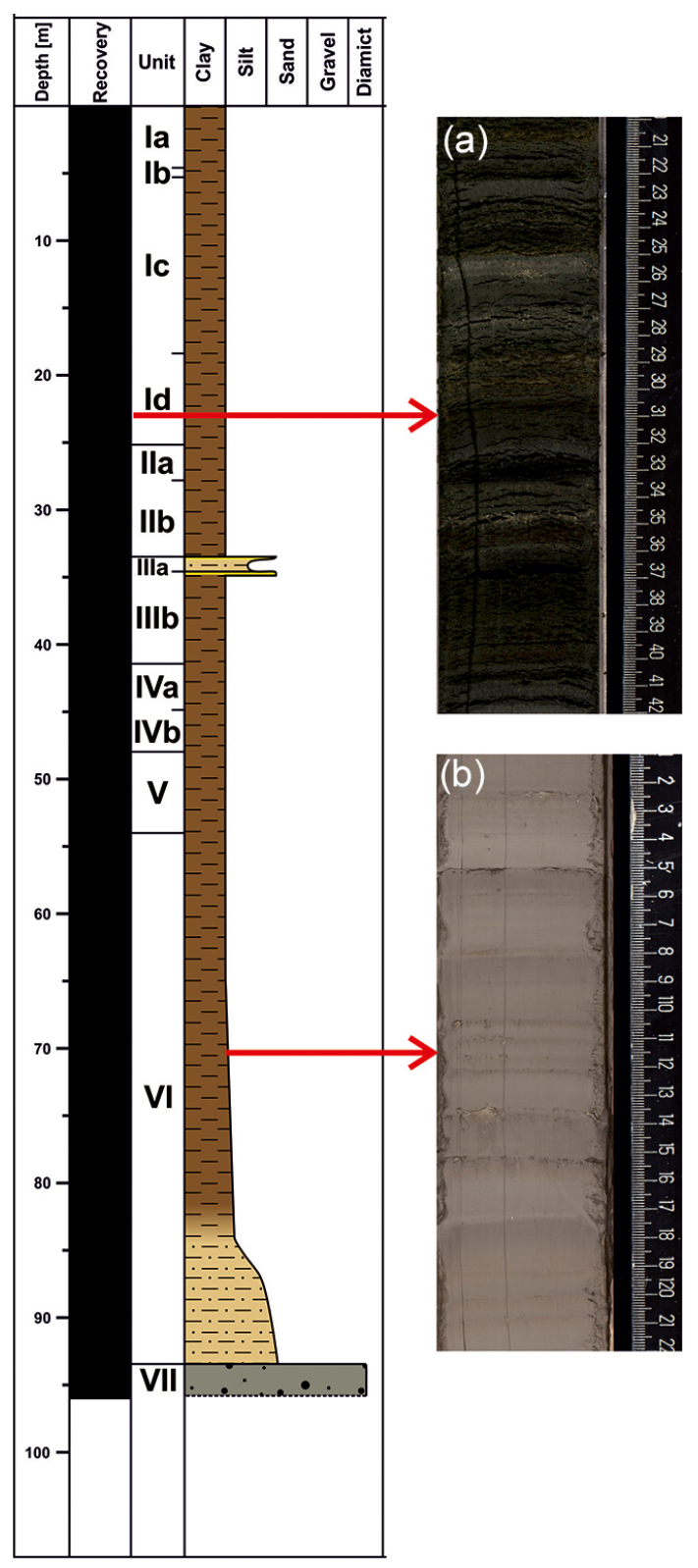

Figure 5. Landsort Deep, site M0063. Lithostratigraphy with insets (a) laminated Littorina Sea mud (section 347-M0063C-12H-2) and (b) varved Baltic Ice Lake glacial clay (section 347-M0063C-34H2).

thickness of $60 \mathrm{~cm}$, which probably corresponds to the dated layer at site M0064.

A shift from freshwater to brackish conditions is recorded in the diatom flora at $10 \mathrm{~m}$ b.s.f. and most probably represents the Ancylus Lake-Littorina Sea transition (Fig. 7). The lowermost part of this unit is laminated whereas the upper $9 \mathrm{~m}$ is homogenous and contains abundant mollusk shell fragments indicating well-oxygenated bottom water conditions. (a)

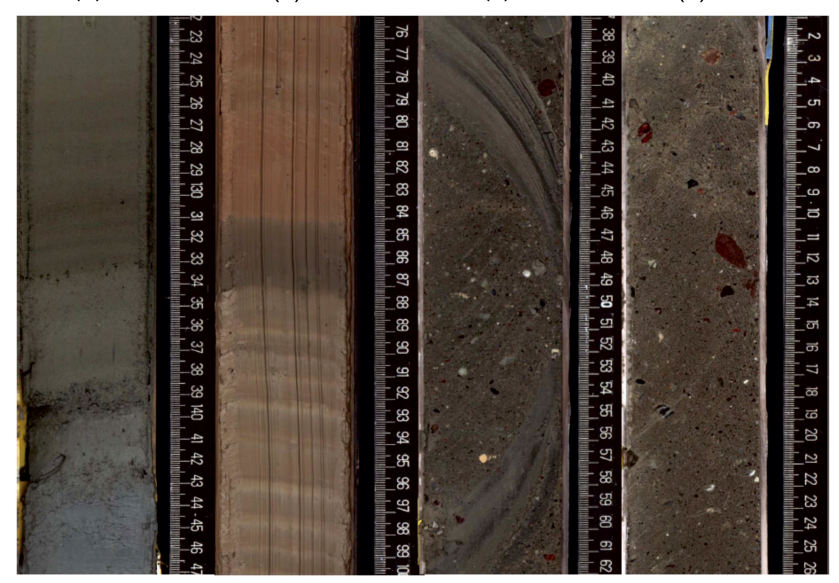

Figure 6. Hanö Bay, site M0064. Examples of varved glacial clay (a and b) and diamicton (c, d). The greyish brown unit between 84 and $87 \mathrm{~cm}$ separating the two different types of varved glacial clays in section b have an age of $45700 \pm 1500$ cal yr BP.

\subsection{Microbiology}

Cell enumeration was done on board the Greatship Manisha by two different approaches. One was the well-established epifluorescence counting of samples in which cells had been DNA stained with the fluorescent dye, acridine orange. The other was flow cytometry whereby cells were first extracted quantitatively from the sediment and DNA stained with the fluorescent dye, SYBR (Synergy Brands Inc.) green. In the flow cytometer, which was provided by the Kochi Core Repository, these cells were counted automatically at a high rate, which increased the capacity for onboard cell counts. Importantly, comparison of the two techniques provided very similar cell numbers in most sediments studied. In some sediment intervals, however, flow cytometry provided lower numbers than fluorescence microscopy. This could be explained by incomplete detachment of cells from exopolysaccharide particles, which prevented counting in the flow cytometer but still enabled microscopic counting.

Microbial cell abundances were extremely high at all sites studied, even exceeding $10^{10}$ cells cm $\mathrm{cm}^{-3}$ in the Bornholm Basin, a new record for the IODP. Cell numbers also remained surprisingly high at depth. This is in accordance with the high organic carbon content in the Holocene deposits and the high sedimentation rates. As an example from site M0059 in Little Belt, the cell density was $10^{9}$ cells cm${ }^{-3}$ at the sediment surface and dropped only by 1 order of magnitude at the bottom of the Holocene at $50 \mathrm{~m}$ b.s.f. where the sediment had an estimated age of $>9000$ years (Fig. 8a). Cell numbers for site M0063 in the Landsort Deep (Fig. 8b) provided another example of a good correspondence between the two enumeration techniques in the lower part of the hole but showed an increasing divergence towards the sediment surface due to the described incomplete dispersion of cells. 


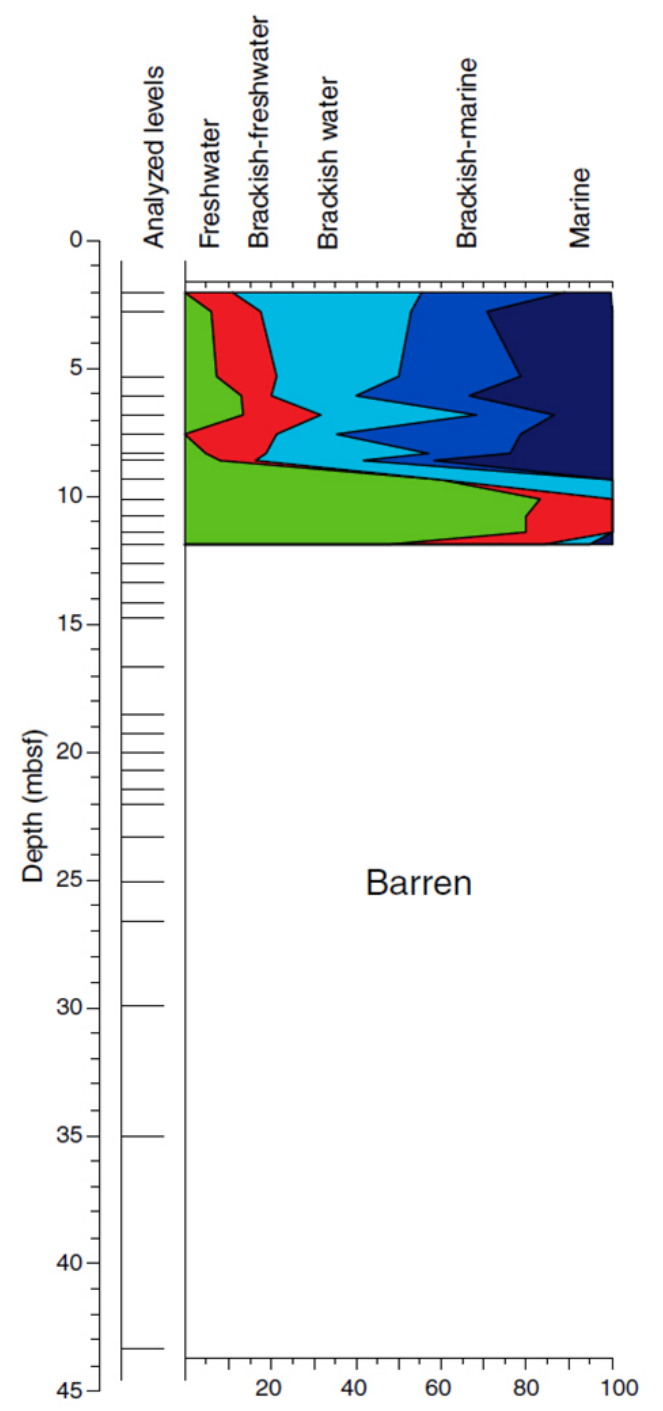

Figure 7. Bornholm Basin, site M0065. Relative distribution of diatom taxa according to their preferred habitat salinity.

Since it was not possible on this mission-specific platform to perform any microbiological analyses other than cell counts, samples needed to be fixed and/or frozen to be preserved for later studies in land-based laboratories. Freezing may damage cell structures and can be a problem for studies that depend on intact cells, such as fluorescence in situ hybridization (FISH or CARD-FISH). However, a new CAS (Cells Alive System) freezer technique, provided by the Kochi Core Repository, was available on board. By this technique samples are cooled during exposure to a high-frequency alternating electromagnetic field. When the temperature reaches $-10^{\circ} \mathrm{C}$ the electromagnetic field is switched off and freezing happens almost instantaneously, which prevents the formation of ice crystals of a size that damages cell structures.
When drilling the holes for microbiology at four sites, contamination tests were carried out (Smith et al., 2000; Lever et al., 2006). A perfluorocarbon (PFC) tracer was pumped continuously into the drilling fluid and samples were taken from three radial positions in each core immediately upon recovery and cutting on the drill deck. As a new procedure for IODP, samples were also taken routinely from fluid remaining in the core liner. Since this represents the fluid to which the cores were exposed when taken in situ, these fluid samples optimally represent the relevant contamination tracer concentration. The results showed that the concentration of the tracer that arrived at the bottom of the drill hole was mostly much lower than the expected target concentration. The conclusion is that this sampling procedure of liner fluid should be implemented on future IODP expeditions. Also the land-based analytical procedure for PFC was improved relative to IODP standard by heating samples while rotating before headspace sampling and GC-ECD (gas chromatography with electron capture detector) analysis (M. A. Lever, unpublished). Furthermore, this procedure is recommended for future deep biosphere expeditions when analyzing a PFC tracer.

During expedition 347, a large number of samples were taken for many different land-based research groups and for many different types of analysis. In fact, the requested sampling frequency was so high in the upper sediment intervals that most of the core was subsampled and it was occasionally difficult to accommodate all the requests. In order to minimize the impact of high levels of sampling, graphical sampling schemes were developed in advance for each core. For the sampling of whole round cores, a small computer program was developed to facilitate the sampling plan (Marshall, 2014). It was also of great advantage on this expedition that samples for land-based studies that relied on live microorganisms could be off-loaded from the Greatship Manisha to a small boat and thereby arrived in the receiving laboratories in Denmark, Germany, and the UK within a few days to a week after coring of each microbiology hole.

\section{Conclusions and future work}

The OSL ages from site M0059 indicate that we reached at least some $350 \mathrm{ky}$ back in time. Without having all dates at hand, we assume that at site M0060 we recovered sediments dating back to the previous interglacial. This means that the lower part of the holes from these two sites may cover the end of MIS 6, MIS 5, and MIS 4, although with partly fragmented stratigraphies.

Sediments of MIS 3 age have been recovered and dated at site M0059 and site M0064 and are most probably also present in the sediments from site M0065 and perhaps also M0066. The recovered sediments, of pro-glacial sandur at site M0059 and organic-bearing clay at site M0064 and M0065, indicate an ice-free event in the middle of the We- 

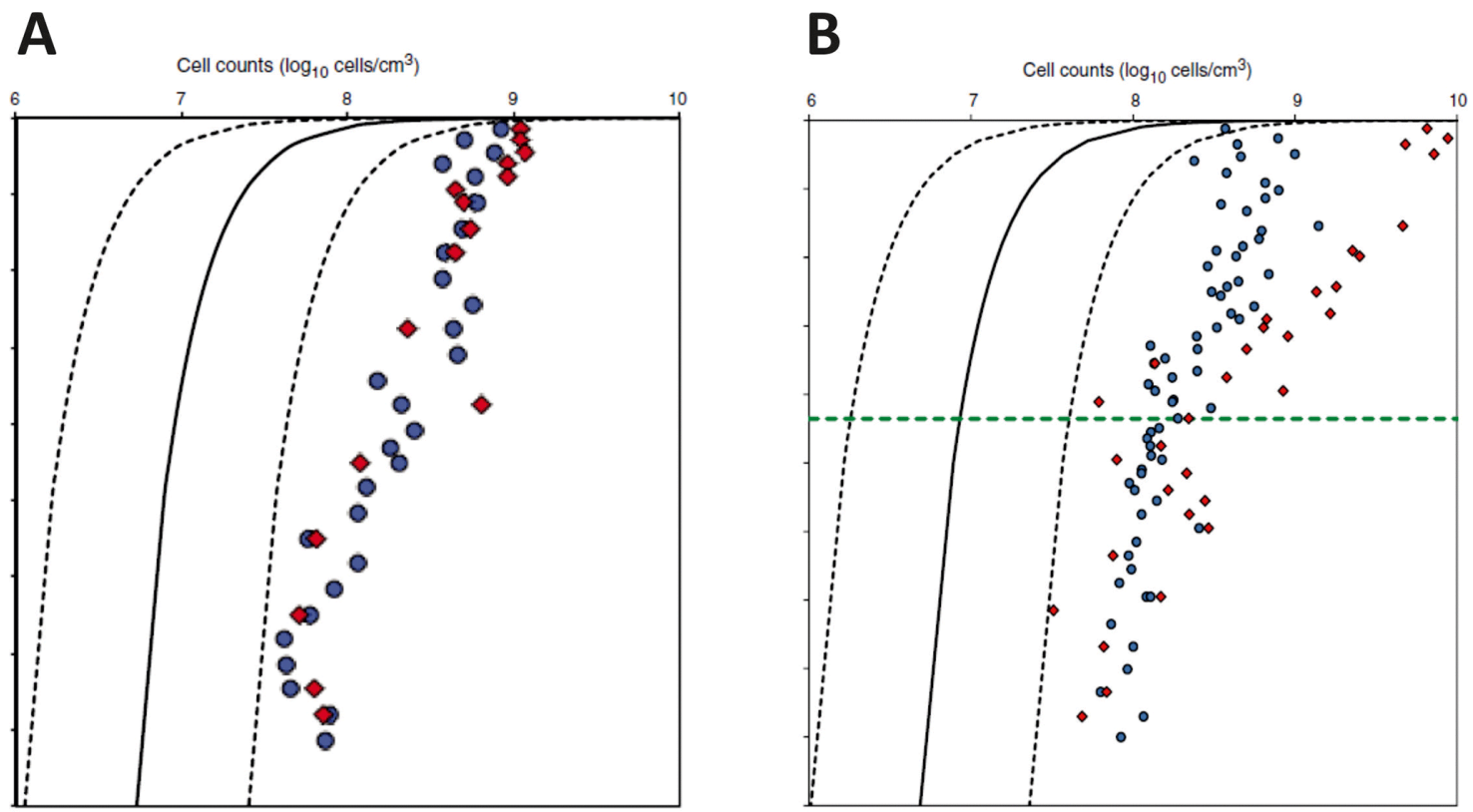

Figure 8. Cell numbers from (a) Little Belt, site M0059, and (b) the Landsort Deep, site M0063. Red diamonds: cell counts by fluorescence microscopy (AODC, acridine orange direct counts); blue circles: cell counts by flow cytometry. The solid black line is a global regression line of prokaryote cell numbers with depth, while the dashed lines are upper and lower $95 \%$ prediction limits for the regression line (Roussel et al., 2008).

ichselian glacial with an age of $44 \pm 4 \mathrm{ky}$ BP. Ongoing analyses of sediments from these sites may shed new light on the history of the BSB and the behavior of the SIS during the enigmatic MIS 3.

Varved glacial clays deposited from the retreating SIS have been recovered at all drilled sites, which makes environmental reconstructions possible with annual resolution. Especially notable are the $52 \mathrm{~m}$ long varved sequences from site M0063, possibly containing as much as 2000 varves and probably covering the entire Younger Dryas. This unique varved sequence will give us new insights into how the SIS responded to climate fluctuations, including the slow cooling at the beginning and the rapid warming at the end of the stadial. It will also give new information on the position of the ice margin and thereby improve the correlation between ice margin positions in eastern Sweden and southwestern Finland during the Younger Dryas.

It should be noted that glacial varves have traditionally been assigned to the latest deglaciation but the two units of varved glacial clay separated by an organic-bearing clay with an age of $45700 \pm 1500$ cal yr BP indicates a different scenario at site M0064. It is obvious that only the upper varved sequence was deposited during the latest deglaciation whereas the lower sequence represents an earlier deglaciation.

Sediments of Holocene age have been recovered at most drilled sites but at sites M0059 and M0063 the thickness of these sediments is spectacular, ca. $52 \mathrm{~m}$ at site M0059 and ca. $45 \mathrm{~m}$ at site M0063. The extremely high sedimentation rates at these two sites presented the possibility to reconstruct the environmental response to climate warming leading up to the Holocene thermal maximum, occurring some 8000 to 5000 years ago, with a resolution never reached before in the Baltic Sea area. It will, for example, be possible to detect small variations in, e.g., salinity, nutrient status, temperature, ice cover, and periods of hypoxia/anoxia, possibly with an annual resolution.

Mission-specific platforms routinely work in shallow waters, and so protocols are already in place to maximize the quality and amount of core recovered when working in these environments, building on the knowledge gained from four previous expeditions. However, the scope of the offshore microbiological program was something not undertaken before on an MSP (mission-specific platforms). Thanks to the early and extensive input and support from the microbiological community, we were able to achieve a successful sampling campaign. However, a detailed post-cruise review has shown areas in which additional protocols need to be established in order to improve results in this discipline, e.g., the addition of the contamination tracer to the drilling fluid at higher concentrations.

During expedition 347, four sites were selected for detailed studies of geochemistry and microbiology. Nearly 6000 samples were taken offshore for interstitial water analyses and microbiological studies. The many chemical analyses done on board the Greatship Manisha and during the onshore phase have generated data of outstanding quality and detail. The results provide novel insights into the geochemical con- 
sequences of glacial to interglacial and fresh-water to marine transitions combined with shifts from low-organic lateglacial clay to high organic Holocene clay with extremely high sedimentation rates. These data will be supplemented by a large diversity of inorganic, organic, and isotope geochemical analyses in laboratories around the world.

Detailed contamination tracer measurements were made during the expedition with improved methods relative to previous IODP standards. Off-loading of microbiology samples shortly after drilling enabled cultivation experiments and studies of microbial activity to be done in land-based laboratories and thereby overcome the limited laboratory facilities on the drillship. A comparison of microbial cell counting techniques showed that flow cytometry can provide data of equally good quality as microscopic counts and thereby may enhance the capacity for cell quantification on future drilling expeditions. A new CAS technology enables the freezing of microbiology samples for sensitive post-cruise microbiology studies that require intact DNA/RNA and cell membranes. A large number of samples are currently being analyzed in many different laboratories and will provide metagenomic, metatranscriptomic, and meta-metabolomic data as well as specific data on microbial process rates, cultivation-based microbial diversity, and other information for archaea, bacteria, and eukaryotic microorganisms as well as viruses.

Based on the preliminary lithological, biostratigraphic, paleomagnetic, dating, geochemical, and microbiological data, we conclude that expedition 347 accomplished most of the objectives that we had outlined in IODP proposal 672. This was indeed a successful expedition.

The full expedition report is available for download from http://publications.iodp.org/.

\section{Team members}

E. Andrén, J. Ash, T. Bauersachs, B. Cragg, A.-S. Fanget, A. Fehr, W. Granoszewski, J. Groeneveld, D. Hardisty, E. Herrero-Bervera, O. Hyttinen, J. B. Jensen, S. Johnson, M. Kenzler, A. Kotilainen, U. Kotthoff, I. P. G. Marshall, E. Martin, S. Obrochta, S. Passchier, N. Quintana Krupinski, N. Riedinger, C. Slomp, I. Snowball, A. Stepanova, S. Strano, A. Torti, J. Warnock, N. Xiao, and R. Zhang.

Acknowledgements. We thank the captain and crew of the Greatship Manisha, the operations superintendents and all the expedition staff and technicians, whose outstanding professional support ensured the successful drilling, sampling, and measurements on expedition 347. We also thank the excellent management, staff and students at the IODP Bremen Core Repository at MARUM, Bremen, for ensuring a very effective and productive onshore sampling party. We thank the proponents and other colleagues, who were engaged in the preparation of IODP proposal 672 for their great efforts that made this expedition happen.
Edited by: U. Harms

Reviewed by: S. Björck and one anonymous referee

\section{References}

Andrén, T., Björck, J., and Johnsen, S.: Correlation of Swedish glacial varves with the Greenland (GRIP) oxygen isotope record, J. Quaternary Sci., 14, 361-371, doi:10.1002/(SICI)10991417(199907)14:4<361::AID-JQS446>3.0.CO;2-R, 1999.

Andrén, T., Lindeberg, G., and Andrén, E.: Evidence of the final drainage of the Baltic Ice Lake and the brackish phase of the Yoldia Sea in glacial varves from the Baltic Sea, Boreas, 31, 226238, doi:10.1111/j.1502-3885.2002.tb01069.x, 2002.

Andrén, T., Björck, S., Andrén, E., Conley, D., Zillén, L., and Anjar, J.: The development of the Baltic Sea basin during the last 130000 years, in: The Baltic Sea Basin, edited by: Harff, J., Björck, S., and Hoth, P., Springer, 75-97, doi:10.1007/978-3642-17220-5_4, 2011.

Bennicke, O. and Jensen, J. B.: A Baltic Ice Lake lowstand of the latest Allerød age in the Arkona Basin, southern Baltic Sea, Geol. Surv. Den. Greenl., 28, 17-20, 2013.

Björck, S.: A review of the history of the Baltic Sea, 13.0-8.0 ka BP, Quat. Int., 27, 19-40, 1995.

Funder, S., Demidov, I., and Yelovicheva, Y.: Hydrography and mollusc faunas of the Baltic and the White Sea-North Sea seaway in the Eemian, Palaeogeogr. Palaeocl., 184, 275-304, 2002.

Houmark-Nielsen, M.: Extent and age of middle and late Pleistocene glaciations and periglacial episodes in southern Jylland, Denmark, Bull. Geol. Soc. Den., 55, 9-35, 2007.

Houmark-Nielsen, M. and Kjær, K. H.: Southwest Scandinavia, 4015 kyr BP: palaeogeography and environmental change, J. Quaternary Sci., 18, 769-786, 2003.

Jakobsson, M., Björck, S., Alm, G., Andrén, T., Lindeberg, G., and Svensson, N.-O.: Reconstructing the Younger Dryas ice dammed lake in the Baltic Basin: bathymetry, area and volume, Global Planet. Change, 57, 355-370, 2007.

Kabel, K., Moros, M., Porsche, C., Neumann, T., Adolphi, F., Andersen, T. J., Siegel, H., Gerth, M., Leipe, T., Jansen, E., and Sinninghe-Damsté, J. S.: Impact of climate change on the Baltic Sea ecosystem over the past 1,000 years, Nature Climate Change, 2, 871-874, 2012.

Kjellström, E., Brandefelt, J., Näslund, J.-O., Smith, B., Strandberg, G., Voelker, A. H. L., and Wohlfarth, B.: Simulated climate conditions in Europe during the marine isotope Stage 3 stadial, Boreas, 39, 436-456, 2010.

Lambeck, K. and Chappell, J.: Sealevel change through the last glacial cycle, Science, 292, 679-686, 2001.

Larsen, N. K., Knudsen, K. L., Krohn, C. F., Kronborg, C., Murray, A. S., and Nielsen, O. B.: Late Quaternary icesheet, lake and sea history of southwest Scandinavia - a synthesis, Boreas, 38, 732761, 2009.

Lever, M. A., Alperin, M., Engelen, B., Inagaki, F., Nakagawa, S., Steinsbu, B. O., Teske A., and IODP Expedition 301 Scientists: Trends in basalt and sediment core contamination during IODP Expedition 301, Geomicrobiol. J., 23, 517-530, doi:10.1080/01490450600897245, 2006.

Liu, Z., Otto-Bliesner, B. L., He, F., Brady, E. C., Tomas, R., Clark, P. U., Carlson, A. E., Lynch-Stieglitz, J., Curry, W., Brook, E., Er- 
ickson, D., Jacob, R., Kutzbach, J., and Cheng, J.: Transient Simulation of Last Deglaciation with a New Mechanism for BøllingAllerød Warming, Science, 17, 310-314, 2009.

Marshall, I. P. G.: Corganiser: a web-based software tool for planning time-sensitive sampling of whole rounds during scientific drilling, Sci. Dril., 18, 1-4, doi:10.5194/sd-18-1-2014, 2014.

Marshall, S. J. and Clark, G. K. C.: North American freshwater runoff through the last glacial cycle, Quaternary Res., 52, 300$315,1999$.

Roussel, E. G., Bonavita, M.-A. C., Querellou, J., Cragg, B. A., Webster, G., Prieur, D., and Parkes, R. J.: Extending the subseafloor biosphere, Science, 320, 1046, doi:10.1126/science.1154545, 2008.

Salonen, V.-P., Kaakinen, A., Kultti, S., Miettinen, A., Eskola, K. O., and Lunkka, J. P.: Middle Weichselian glacial event in the central part of the Scandinavian Ice Sheet recorded in the Hiturapit, Ostrobothnia, Finland, Boreas, 37, 38-54, 2007.

Smith, D. C., Spivack, A. J., Fisk, M. R., Haveman, S. A., Staudigel, H., and the Leg 185 Shipboard Scientific Party: Methods for quantifying potential microbial contamination during deep ocean coring, ODP Tech. Note, 28, p. 1-19, doi:10.2973/odp.tn.28.2000, 2000.
Sohlenius, G., Emeis, K.-C., Andrén, E., Andrén, T., and Kohly, A.: Development of anoxia during the fresh-brackish water transition in the Baltic Sea, Mar. Geol., 177, 221-242, 2001.

Walker, M., Johnsen, S., Olander Rasmussen, S., Popp, T., Steffensen, J.-P., Gibbard, P., Hoek, W., Lowe, J., Andrews, J., Björck, S., Cwynar, L. C., Hughen, K., Kershaw, P., Kromer, B., Litt, T., Lowe, D. J., Nakagawa, T., Newham, R., and Schwander, J.: Formal definition and dating of the GSSP (Global Stratotype Section and Point) for the base of the Holocene using the Greenland NGRIP icecore, and selected auxiliary records, J. Quaternary Sci., 24, 3-17, doi:10.1002/jqs.1227, 2009.

Zillén, L., Conley, D. J., Andrén, T., Andrén, E., and Björck, S.: Past occurrences of hypoxia in the Baltic Sea and the role of climate variability, environmental change and human impact, Earth Sci. Rev., 91, 77-92, 2008. 